\title{
Tax burden and economic growth in Lesotho: An estimate of the optimal tax burden
}

\author{
Nthabiseng Koatsa ${ }^{a}$, Ch. Paramaiah ${ }^{b^{*}}$ and Manaka Scona ${ }^{c}$
}

${ }^{a}$ Department of Economics, National University of Lesotho, Roma, Lesotho

${ }^{b}$ Associate Professor, School of Business, Skyline University College, University City, Sharjah, United Arab Emirates ${ }^{c}$ Lesotho Revenue Authority, Lesotho

\section{H R O N I C L E}

\section{Article history:}

Received: August 10, 2020

Received in revised format:

November 152020

Accepted: November 27, 2020

Available online:

December 4, 2020

Keywords:

Tax burden

Tax rate

Economic growth and optimal tax

\section{A B S T R A C T}

Lesotho faces fiscal deficits due to high government expenditure as characterized by the huge wage bill regarded as one of the highest in the world (UNICEF, 2018). The aim of this research paper is to investigate the tax revenue impact as a share of Gross Domestic Product (GDP) on economic growth in Lesotho. This research is provoked by the theoretical postulations and empirical evidence that their relationship is positive up to a certain optimal level which is the point at which economic growth rate is maximized. The study used data from 1988 to 2017 to investigate the relationship between tax burden and economic growth in Lesotho by applying the log-linearized model of Scully's tax optimization model transformed into an ARDL bounds testing framework. Granger causality test and error correction model was employed to investigate the long run relationship between tax burden and economic growth in Lesotho. The findings of study revealed a long-run relationship between economic growth rate and tax burden with a unidirectional causality running from economic growth to tax burden. Granger causality revealed no causal effect running from tax burden to economic growth in Lesotho despite expectation of significant causal effect following both theoretical and empirical literature from various studies. Error correction results further supported a co-integrating relationship running from economic growth to tax burden with 100 percent speed of adjustment in the short-run towards a long-run equilibrium level. An optimal tax burden could not be established as the variables of interest were negative and insignificant signifying the insignificance of tax policy in stimulating the economic performance.

(c) 2021 by the authors; licensee Growing Science, Canada

\section{Introduction}

Post-2007/2008 global financial crisis, the allocation of Southern African Customs Union (SACU) receipts to Lesotho has declined from an average of 25 percent of Gross Domestic Product (GDP) in the year 2009/2010 to 12 percent in 2010/2011 of the GDP. However, the performance recovered massively in 2012/2013 reaching 24 percent of GDP (IMF, 2017). The Country faced significant balance of payment needs during this period and was bailed out by the International Monetary Fund (IMF) to ensure adequate fiscal and external buffers. In 2017/18 fiscal year, 23.5\% of GDP was realized in the form of SACU receipts; however, a decline of M616.1 million was recorded in 2018/2019 from its 2017/2018 level (Budget Speech, 2018). This highlights the importance of mobilizing domestic resources to guard against external shocks which have proven to be harmful to Lesotho economy. In the past two fiscal years; 2016/2017 and 2017/2018, the Lesotho Revenue Authority missed its set tax revenue targets of M7, 298.7 million and M7, 604.3 million, respectively. However, the tax revenue target level was increased for the 2018/2019 fiscal year despite poor performance in the previous year, and the government expenditure was reported to be moving up its trajectory notwithstanding proposed fiscal consolidation in the previous budget allocation.

* Corresponding author.

E-mail address: channaganu.paramaiah@skylineuniversity.ac.ae (Ch. Paramaiah) 
Increased government expenditure is characterized by the huge wage bill reported amongst the highest in the world considering the size of Lesotho economy (IMF, 2017). Lesotho's Government wage bill has increased from 10 percent of GDP in the last two decades to 19 percent in the year 2018 and its growth has been financed by the reduction in the share of goods and services, which has cumulatively reduced the labor productivity of the civil service (Budget Speech, 2018). The implication of the increasing tax revenue targets signifies desperation of the Lesotho government of trying to finance its budget expenditures.

Over the years, taxation and economic growth relationship has been a topical issue discussed by various researchers in their studies. However, consensus on their relationship has never been reached as various studies reached conflicting results. Some studies found that the effects of tax increases are contradictory to growth (Romer \& Romer, 2010; Khumbuzile \& Khobai, 2018). Conversely, other studies found the relationship between taxation and economic growth is positive and taxation is a strong economic tool for economic prosperity (Jayeola et al., 2018; Babatunde et al., 2016). As a vital instrument of fiscal policy, the importance of taxation in an economy cannot be overlooked. It is a financial charge imposed upon the taxpayers and is regarded as the profound source of government revenue for financing of public expenditures. Lesotho's share from the SACU receipts to total government revenue was recorded at 42.2 percent in 2011/2012 financial year, but recovered and peaked at 59.9 percent in 2012/2013 financial year, however it eventually moved down its trajectory path reaching 52.2 percent in 2015/2016 fiscal year (LRA, 2016). In his paper Thamae (2013), Lesotho's high dependency on SACU revenues exposes the country as more external shocks and therefore domestic revenue collections used to be enhanced.

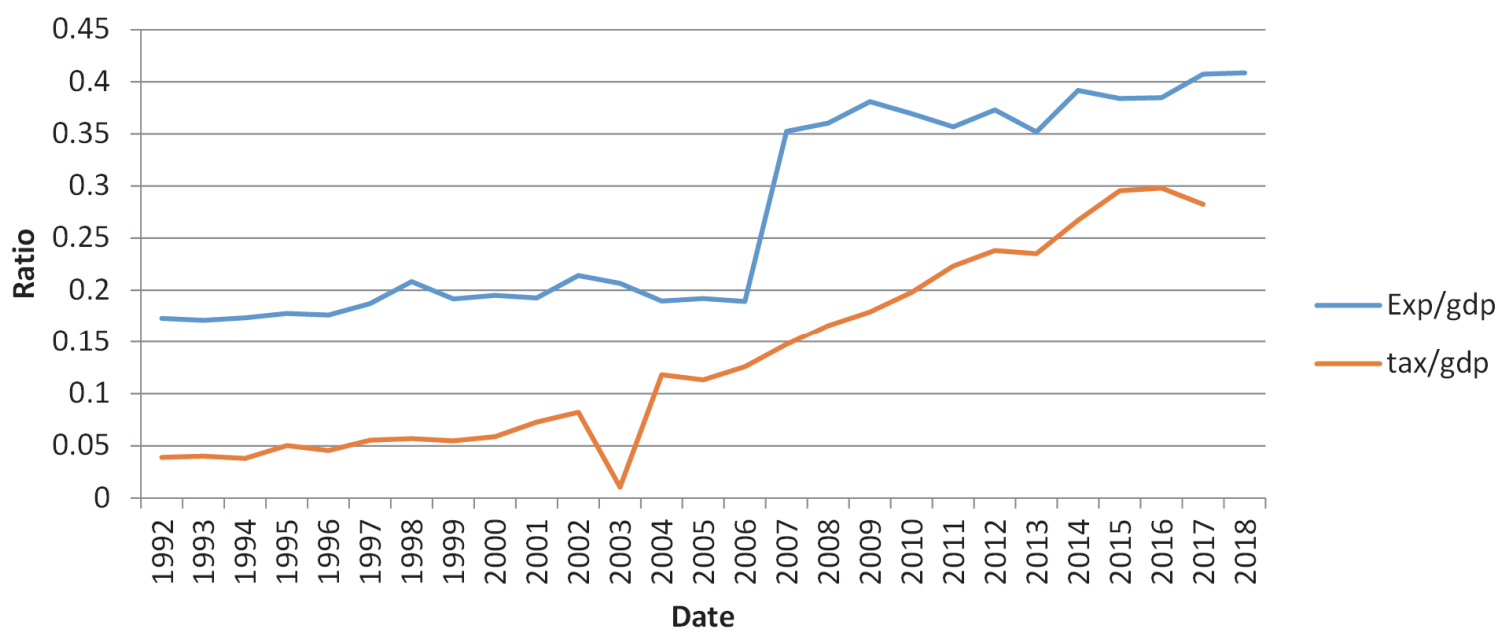

Fig. 1. Tax Revenue to GDP and Expenditure to GDP Ratios in Lesotho During 1992 to 2018

Source: Authors computations using Central Bank of Lesotho and Lesotho Revenue Authority

It is evident from the figure 1 that both expenditure to GDP and Tax revenue to GDP for the period 1992 to 2018 show that the government supplements tax revenues with other sources of financing such as deficit financing and SACU receipts to meet its expenditure obligations. Contributing to more than half of government revenue, SACU receipts play an important role in financing government expenditure. Declining SACU receipts therefore signifies the importance of exploring other sources of financing the country's expenditure in order to enhance economic development and boost economic growth. To finance its expenditure, the government has; debt financing (through external financing); money creation and; taxation as the main tools at its disposal to meet its obligations. The money creation cannot be freely utilized since Lesotho lost its monetary policy power following its membership to the Common Monetary Area.

\subsection{Overview of Lesotho's Tax system}

The government of Lesotho, like many other governments across the world, finances its recurrent and capital expenditures through revenues collected. Government revenue comprises both Non-tax revenue and tax revenue. Tax revenue has since been collected by the government of Lesotho from the late 1960's with various tax reforms put in place until in 2003 when the then Income Tax, Customs and Excise and Sales Tax Departments were merged to form Lesotho Revenue Authority (LRA). The transformation was facilitated with a view of improving the efficiency and effectiveness of the tax administration in revenue collection and provision of quality service to the public. 


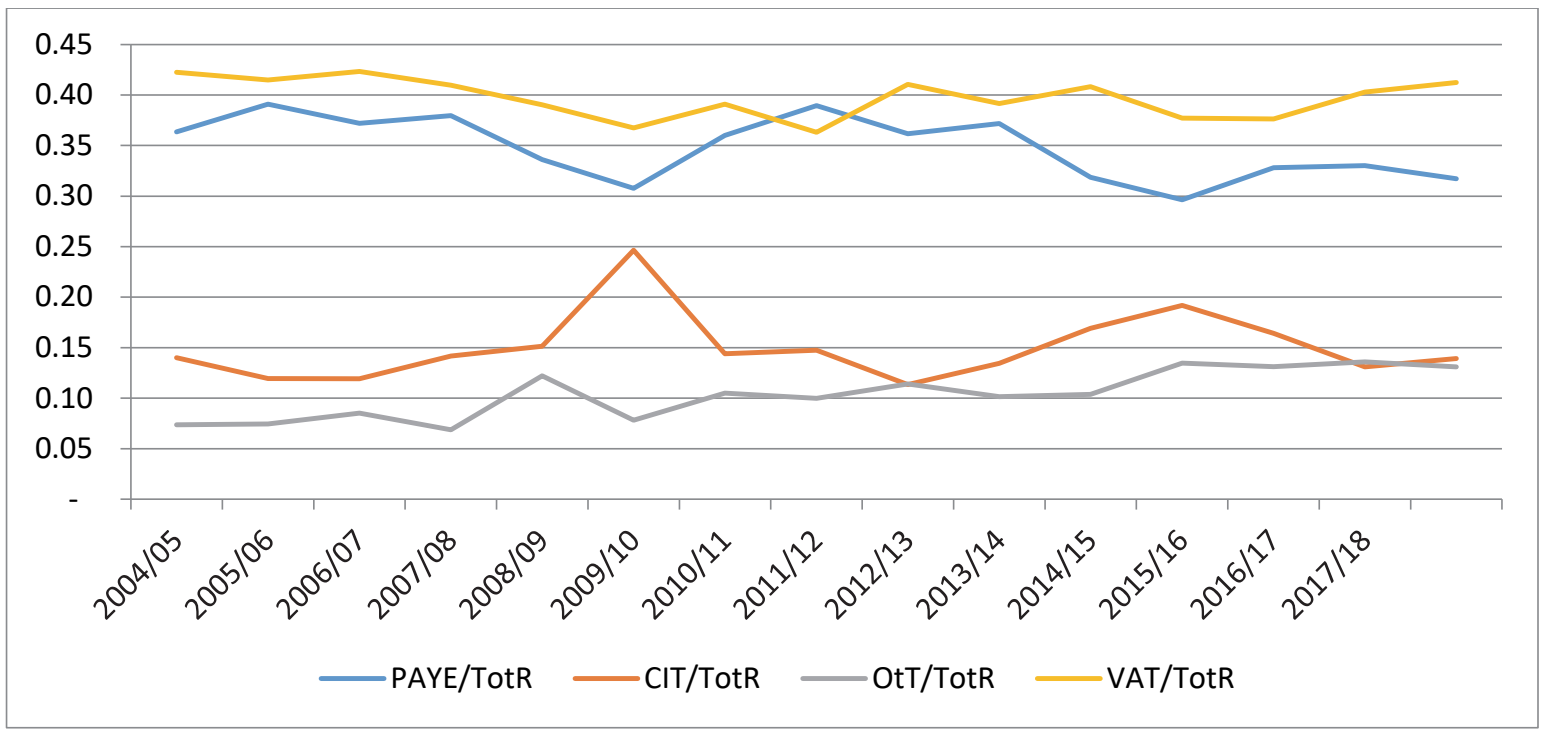

Source: Lesotho Revenue Authority

Fig. 2. Contribution of different tax types to Total revenue from 1992-2017

Fig. 2, illustrates trends in the percentage of contributions to total tax revenue by Pay as You Earn (PAYE), Company Income Tax (CIT), Value Added Tax (VAT) and other taxes comprising of withholding taxes and fringe benefit taxes amongst others. Since establishment of the LRA, VAT is seen to have been the main contributor of all tax types to total tax revenue for the period 2004-2018 followed by PAYE. PAYE peaked around 2011/2012 fiscal year and is spotted to have been moving down its trajectory until present. This could have been a result of closing of various exporting textile firms due to the $2008 / 2009$ global output recession. Company income tax (CIT) contribution to tax revenue has been on an upward spiral until 2009/2010 financial year when a sharp turning point was realized. The steep downward trajectory of CIT was a result of closure of many textile firms in manufacturing sector following the 2008/2009 global financial crisis. Other taxes enjoyed a stable growth during the period with insignificant fluctuations relative to other taxes.

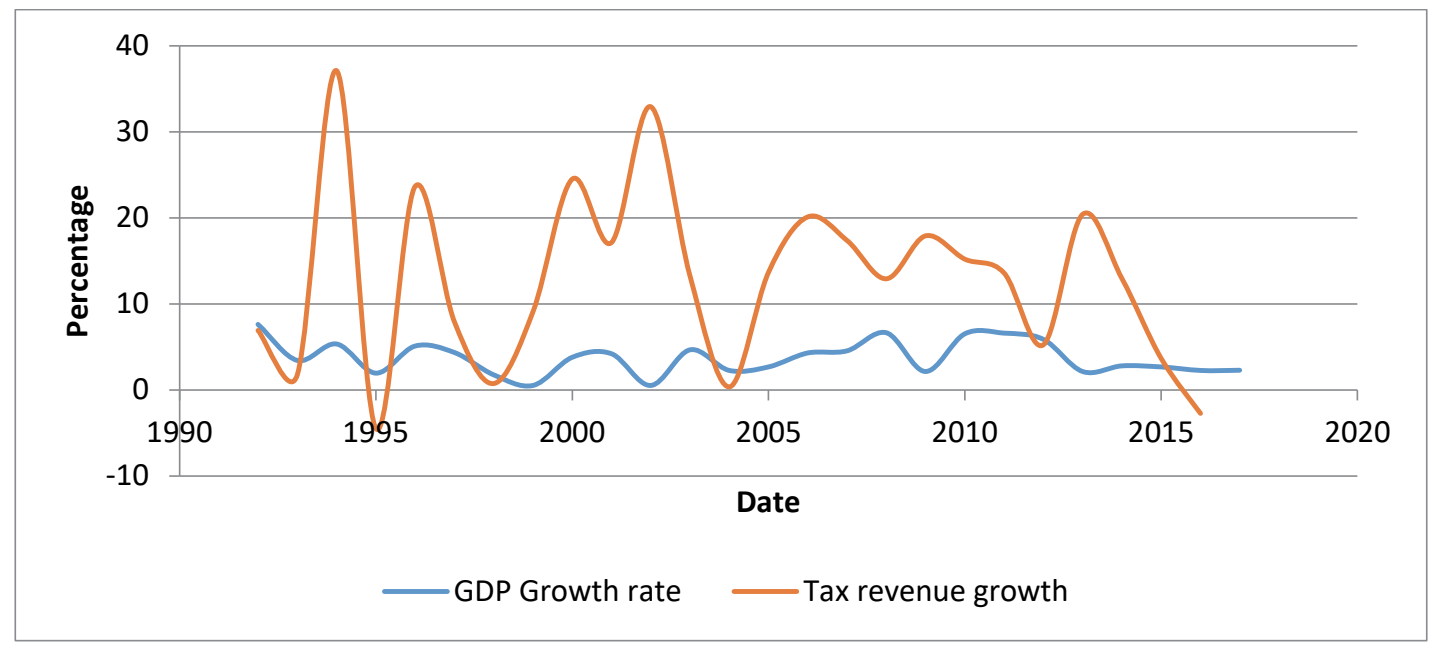

Fig. 3. GDP growth rate and Tax revenue growth rate relationship in Lesotho

Source: Central Bank of Lesotho and Lesotho Revenue Authority

As shown in Fig. 3 3, from 1992 to 1999 the growth rate of GDP has been declining on average. This could have been a result of political unrest that surfaced the country in 1993 and 1998 that saw most if not all businesses put to a halt, leading to job losses. Lowest growth rates were realized in around 1999 and $2002(0.54 \%$ and $0.53 \%$ respectively) presumably as a result of political unrest in the country in 1998 that led to distorted economic activities. From 2003, growth was experienced until the period of global financial crisis, 2007/2008, which saw many economies suffering a major shock due to inflationary pressures and distortion in production, of which Lesotho was no exemption. The economic performance recovered in 2010 and growth was recorded at $6.53 \%$ from $2.2 \%$ realized in 2009 . However, growth rate is seen to be moving down its trajectory from 2012 
until a recent record of $2.3 \%$ in 2017 . The downward spiral of the growth rate could be a result of political instability surfacing in the country that saw change of three governments in a period of five years.

Amgain (2017) compliments that there is a certain level of tax revenue in GDP that is required to maintain fiscal sustainability. High levels of taxation discourage both investment and supply of labor resulting in reduced growth; also, lower levels of taxation create a resource gap and therefore impede public investments. As both investment and labor supply are reduced, the tax base will shrink and the tax revenue reduced ultimately (Halkos \& Paizanos, 2015). Attila (2011) posits that, with the same analogy as that of the Laffer curve, increasing the tax pressure could lead to adverse effects on economic activities thereby harming growth of an economy. This is to say, the benefits derived from taxation revenue may be offset by negative effects on growth because of higher taxes

\subsection{Objectives of the study}

The government of Lesotho's much reliance on the SACU receipts and external financing necessitates exploring other sources of financing the country's expenditure to enhance economic development and boost economic growth. In this paper an attempt has been made to examine the relationship between tax burden and economic growth in Lesotho and to determine the optimal tax burden in Lesotho

\subsection{Hypothesis of the Study}

The study seeks to test the following null hypotheses:

- There is no relationship between tax burden and economic growth in Lesotho.

- The current tax burden is not optimal in Lesotho

\section{Literature Review}

In public finance, a tax burden is measured in two ways, it can be calculated as a cash payment as a result of a tax rate imposed or charged. Secondly, by determining the losses imposed on taxpayers as a consequence of the tax. The former is defined as a share of tax revenue to GDP. Koch et al. (2005) define a burden of a tax impacts the decrease in economic activity or deadweight loss. Which indicates that a reduction in economic activity of all sectors of the economy expected to be negatively impact on economic growth of a country. Keynes (1936) advocated the role of the government intervention through fiscal policy in influencing economic activities. He also supported the ideology that the role of the aggregate demand stimuluses the level of output an economy. The understanding of the Keynesian theory is that taxation influences the level of disposable income and aggregate output demanded thereby affecting the amount of output. The theoretical underpinnings of taxation and economic growth indicates the negative and positive relationship of both variables. The negative relationship is due to distortions and discouragement factors inherent in taxation, and the positive relation is indirectly due to the expenditures financed through taxation (Takuma \& Iyke, 2015).

Supply-side economics is the branch of economics that deals with the factors affecting the productive capacity of the economy. Supply-side economic policies affect the economic growth of an economy through the tax component of fiscal policy (Macek, 2014). More emphasis is put on efficiency of resource allocation and economic growth. A balanced supply-side program consists of; tax cuts on personal income tax as well corporate income tax. A reduction in the amount of public expenditures appropriately with tax cuts and deregulation; and provides high productivity economic growth and stable prices (Evans, 1983). A reduction in taxation provides high market output and high tax revenue in the long-run. Lower tax rates increase supply of labor and causes economic activities to shift from the underground economy to the market economy (Aktan, 1989).

An increase in taxation is viewed as stimuli to loss of efficiency in an economy which is often termed deadweight loss or excess tax burden because it reduces both the consumer and producer surplus which does not all accrue to the government. The size of the deadweight loss grows as the tax rate is increased. The implication is that higher rates of taxation lead to higher loss of efficiency in an economy which then results in lower economic growth. Macek (2014) posits that government should reduce corporate taxation, personal income tax and taxes on social security contributions.

Amgain (2017) estimated the optimal level of taxation for 32 Asian countries employing data from 1991 to 2012, the author utilized the basic Scully model and quadratic model. The results of the study as per the two models employed revealed an $18 \%$ share of GDP as the growth maximizing tax burden. The results support the theoretical proposition that there is a level of tax at which growth is maximized.

Liu (2012) applied both the qualitative and quantitative analysis method to study the nature of the relationship between tax burden and growth in Vietnam for the period of 10 years (2002-2011). By employing the quantitative analysis method, the study found that Vietnam's economic growth rate is significantly influenced by the tax burden level. The qualitative method proved existence of excess tax burden of $22.8 \%$ and low economic growth rate of $6.55 \%$ comparatively to China, with relatively lower tax burden level of $18.17 \%$ and higher average economic growth rate of $10.16 \%$. 
Saibu (2015) and Chokri et al. (2018) estimated the optimal tax rates for South Africa using quarterly data for periods 19942016 by employing ARDL bounds testing approach. The results reveal that no significant relationship between taxation and economic growth during the period of study. Keho (2010) estimated the optimal tax burden for the Ivorian economy using both Scully and quadratic regression models by employing time series data during $1960-2006$. The findings are in conformity with the proposition that higher tax rates are harmful for growth. Chokri et al. (2018) employed both the Scully's basic model and the quadratic model to estimate the optimal tax burden for Tunisia by using time series data from 1966 to 2015 . The study results revealed that optimal tax burden as between $12.8 \%$ and $19.6 \%$ of GDP.

\section{Methodology}

The study employed annual time series data collected for tax burden and economic growth covering the period from 1988 to 2017. The study period was restricted due to unavailability of data in the preceding years forcing a smaller sample size. GDP growth rate is proxy for economic growth and the proportion of tax revenues to GDP is used as a proxy for tax burden. Data used was sourced from Lesotho Revenue Authority and the Central Bank of Lesotho's online data portal. To examine the short-run and long-run relationship between tax burden and economic growth Scully's log-linearized basic model used which was transformed into an Auto Regressive Distributed Lag (ARDL) model.

\section{The Scully Model}

The study adopts the same methodological approach followed by Saibu (2015) and Matloja et al. (2016) as developed by Scully (2003) and further adapted by Keho (2010) to explore the link between tax burden and economic growth rate in Lesotho. The model was chosen because of its simplicity in deriving the optimal tax rate. The main assumption underlying development of the model specification is that government activities are financed through tax revenue collected, and untaxed part of the national income is used in the private sector for production of goods. The model takes the form of the Cobb-Douglass production function which assumes constant returns to scale:

$$
Y_{t}=a\left(G_{t-1}\right)^{b}\left[(1-\tau) Y_{t-1}\right]^{c},
$$

where $G_{t-1}$ represents the government expenditure in the previous period, $Y_{t}$ is the National output and $\tau$ is the tax burden rate defined as a share of tax revenue to GDP. The model assumes a balanced budget whereby all the government activities are financed by tax revenue.

$$
\mathrm{G}=\tau Y \text {. }
$$

This implies that by substituting Eq. (2) into Eq. (1), the model becomes:

$$
Y_{t}=a\left(\tau Y_{t-1}\right)^{b}\left[(1-\tau) Y_{t-1}\right]^{c}
$$

where $a, b$ and $c$ are parameters such that $b, c$ ranges between 0 and 1 and $\mathrm{c}=1-\mathrm{b}$. The above model is lagged on the right hand side due to the assumption that, the GDP or growth rate in the current period is influenced by the tax revenue or spending in the previous period. The economic growth rate of an economy is equal to output at time $\mathrm{t}\left(Y_{t}\right)$ and is divided by output in the preceding period $\left(Y_{t-1}\right)$ and can also be written as $1+\mathrm{g}$, where $\mathrm{g}$ is the percentage rate of economic growth. Therefore, dividing by $Y_{t-1}$ on both sides of Eq. (3):

$$
\begin{aligned}
& Y_{t} /_{t-1}=1+g=\frac{a\left(\tau Y_{t-1}\right)^{b}\left((1-\tau) Y_{t-1}\right)^{1-b}}{Y_{t-1}} \\
& Y_{t} /_{Y_{t-1}}=1+g=a \tau^{b}(1-\tau)^{1-b}
\end{aligned}
$$

Transforming the model in logarithmic form reduces to:

$$
\log (1+g)=\log a+\operatorname{blog} \tau+\operatorname{cog}(1-\tau)
$$

$\tau$ represents tax burden whereby the share of tax revenue to GDP is used as its proxy and can therefore be written as: $\operatorname{tax} R / g d p$, where $\operatorname{tax} R$ refers to tax revenue and $(1-\tau)$ refers to the share of private receipts to GDP and can be written as: ${ }^{\text {privR }} / g d p$, such that Eq. (6) becomes:

$$
\log (1+g)=\log a+\operatorname{blog}(\operatorname{tax} R / g d p)+c \log \left(\text { priv } R^{\prime} / g d p\right)
$$


To estimate the optimal tax burden rate in the short-run, the maximization principle requires differentiating equation 6 with respect to $\boldsymbol{\tau}$. This yield:

$$
\frac{\partial(1+g)}{\partial \tau}=\frac{b}{\tau}-\frac{c}{1-\tau}=0
$$

Rearranging for the optimal tax rate maximizing economic growth;

$$
\tau^{*}=\frac{b}{b+c}
$$

Kennedy (2000) and Hill (2008) criticized the Scully framework citing production of spurious estimates of an optimal tax rate since the production function specified ignores the contribution of previous periods' capital goods to output since it is an endogenous growth model.

\subsection{The ARDL cointegration model and testing}

One of the objectives of the study is to analyze the relationship between tax burden-measured as tax revenue as a share of GDP, and economic growth in Lesotho. The study applied an ARDL bound test of Pesaran et al. (2001) to investigate the long run relationship between economic growth rate, tax burden and share of private receipts to GDP. Scully's log-linearized model (Eq. (7)) is transformed into an ARDL model to test the cointegration relationship of tax burden and economic growth. The model is specified as follows:

$$
\begin{aligned}
& \Delta \log g d p_{t}=\alpha_{0}+\sum_{i=0}^{n} \alpha_{1 t} \Delta \log \frac{\operatorname{tax} R}{g d p} t-i+\sum_{i=0}^{n} \alpha_{2 t} \Delta \log \frac{\operatorname{priv} R}{g d p} t-i \\
& +\sum_{i=0}^{n} \alpha_{3 t} \Delta \log g d p_{t-i}+\sigma_{1} \log \operatorname{taxR}_{/ g d p_{t-1}}+\sigma_{2} \log { }^{p r i v R} / g d p_{1 t}+\sigma_{3} \log g d p_{1 t}+\epsilon_{t}
\end{aligned}
$$

where $\alpha_{1}, \alpha_{2}$ and $\alpha_{3}$ are the short-run parameters; $\sigma_{1}, \sigma_{2}$ and $\sigma_{3}$ represent long-run parameter estimates, and $\varepsilon_{t}$ is an error term.

The null hypothesis of no co-integration is:

$$
H_{0}=\sigma_{1}=\sigma_{2}=\sigma_{3}=0
$$

And alternative hypothesis of co-integration among the variables is:

$$
H_{1}=\sigma_{1} \neq \sigma_{2} \neq \sigma_{3} \neq 0
$$

The decision about rejection or acceptance of the null hypothesis is based on the calculated F-statistics by Perasan et al. (2001). The upper bound critical value assumes that all the variables are integrated at 1st difference whereas the lower bound critical value assumes that all variables are integrated at level. If the calculated F-statistic is greater than the upper bound critical value then series is co-integrated. Conversely, when the lower critical bound is greater than the F-statistics, there is no co-integration. The result is regarded inconclusive if the calculated F-statistics ranges between the lower critical bound and the upper critical bound forcing us to rely on the lagged error correction term to determine co-integration.

\section{The Analysis of Data}

The data was first analyzed using the summary statistics shown in Table 1, which presents the dimensions that will be used in this paper. The descriptive analysis provides summary of the data based on the number of observations, standard deviation, mean, and the minimum and maximum value.

Table 1

Descriptive statistics

\begin{tabular}{llllll}
\hline Variable & Obs. & Mean & Std. Dev. & Min. & Max. \\
\hline GDP growth rate (RGDP) & 30 & 3.93 & 2.32 & -2.28 & 8.55 \\
Tax burden (Tax Rate//GDP) & 30 & 0.12 & 0.09 & 0.03 & 0.30 \\
Private Receipts (Private Receipts /GDP) & 30 & 0.88 & 0.09 & 0.70 & 0.97 \\
\hline
\end{tabular}

The statistics show that Lesotho's economy has been growing at an average of $3.93 \%$ during the period under study, with the minimum record level of $-2.28 \%$ and a maximum growth of $8.55 \%$. Tax burden recorded an average of $12 \%$ with a minimum and maximum of 3\% and 30\% respectively. In terms of variability of the variables, economic growth shows more variability than tax burden as shown by the higher standard deviation showing that the growth rate is relatively responsive to shocks. 


\subsection{Unit root testing and results}

Augmented Dickey Fuller and Phillips-Perron unit root tests were conducted to check the presence of a unit root in variables. Table 2 presents the Phillips-Perron and Augmented Dickey-Fuller unit root results for private receipts (lprivrgdp) and the two variables of interest; tax burden (ltaxrgdp) and economic growth (lrgdp). The optimal lag lengths for each variable in the model were established by the Akaike Information Criterion (AIC) due to its superiority over other criterion. The null hypothesis of a unit root is tested against an alternative hypothesis of no unit root. If the absolute value of the test statistic is higher than the absolute value of the critical value, the null hypothesis of a unit root is rejected, implying that the variable in question is stationary. Put otherwise, if the value of the test statistic is more negative than the critical value, the null is rejected in favor of the alternative. If the absolute value of test statistic value is lower than the absolute value of the critical value, we fail to reject the null hypothesis of a unit root; therefore, the variable is non-stationary. The unit root test results presented in Table 2 show that the log of real gross domestic product and $\log$ of tax revenue to gross domestic product ratio are stationary at levels while the log of private receipts to gross domestic product ratio is stationary at first difference using both unit root testing approaches. After confirming the stationarity of the variables, the least squares regression may then be performed since time series data is stationary and therefore uphold the necessary classical linear regression assumptions.

Table 1

The Augmented Dickey Fuller and Phillips-Perron Tests Results

\begin{tabular}{llllll}
\hline Variable & Variables in levels & & \multicolumn{2}{l}{ Variables at first differences } & Conclusion on order of integration \\
\hline & ADF statistics & PP statistics & ADF statistics & PP statistics & \\
\hline Lrgdp & $-4.9742 *(0.0005)$ & $-4.9811^{*}(0.0443)$ & & & \\
ltaxrgdp & $-2.6774 *(0.0093)$ & $-2.7170^{*}(0.0084)$ & & & \\
lprivrgdp & & & $5.1234 *(0.0067)$ & $-3.1910 * *(0.0313)$ & $\mathrm{I}(0)$ \\
\hline
\end{tabular}

$*$ and $* *$ denote the level of statistical significance at $1 \%$ and $5 \%$, respectively.

\subsection{The relationship between tax burden and economic growth}

As discussed in the introduction to this paper, in order to test for the existence of any long-run relation amongst the variables we employ the ARDL bounds testing approach to co-integration. Table 3 and 4 present the critical values as developed by Narayan (2005) and the estimated F-statistics from the ARDL regression, respectively. According to Narayan (2005), the existing critical values in Pesaran et al. (2001) cannot be applied for small sample sizes since they are based on large sample sizes. Therefore, Narayan (2005) provides a set of critical values for small sample sizes, ranging from 30 to 80 observations which this study relies on due to a smaller sample size of 30 observations.

Table 2

Critical value bounds of F-Statistic; intercept and no trend

\begin{tabular}{cccccccc}
\hline K=2 & \multicolumn{2}{c}{ CV (1\%) } & \multicolumn{2}{c}{ CV (5\%) } & \multicolumn{2}{c}{ CV (10\%) } \\
\hline & $\underline{\mathrm{I}(0)}$ & $\underline{\mathrm{I}(1)}$ & $\underline{\mathrm{I}(0)}$ & $\underline{\mathrm{I}(1)}$ & $\underline{\mathrm{I}(0)}$ & $\underline{\mathrm{I}(1)}$ \\
\hline & 6.183 & 7.873 & 4.267 & 5.473 & 3.437 & 4.470 \\
\hline
\end{tabular}

Note: $\mathrm{CV}=$ Critical values taken from Narayan (2005)

Table 3

Co-integration test results

\begin{tabular}{cccc}
\hline Model & & F-Statistic & Inference \\
& $\boldsymbol{F}_{\text {lrdgp }}($ lrgdp $\backslash$ ltaxrgdp,lprivrgdp $)$ & 7.7427 & Co-integration \\
& $F_{\text {ltaxr }}($ ltaxrgdp $\backslash$ lrgdp, lprivrgdp $)$ & 1.9233 & No Co-integration \\
& $F_{\text {lprivr }}($ lprivrgdp $\backslash$ ltaxrgdp, lrgdp $)$ & 6.5662 & Co-integration \\
\hline
\end{tabular}

The results show that, when the economic growth rate is a dependent variable, the null hypothesis of no co-integration is rejected since the calculated $F$-statistic (7.7427) is higher than the upper-bound critical value (5.473) at 5\% significance level. This finding is in line with Keho (2010)'s view that higher economic growth creates a broader tax base which would result in higher tax revenue. Conversely, when tax burden (ltaxrgdp) is the dependent variable, the computed $F$-statistic (1.9233) falls below the lower-bound critical value (3.437) at 10\% level of significance and therefore the null hypothesis of no co-integration cannot be rejected. When the share of private receipts is the dependent variable, the null hypothesis of no co-integration is rejected due to calculated F-statistic (6.5662) that is higher than the upper bound critical value (5.473) at 5\% significance level. This shows that there is co-integrating relationship between economic growth rate and tax burden as the variables of interest. The confirmation of significant long-run relationship between economic growth and tax burden permits the estimation of the long-run ARDL coefficients and optimal tax burden.

\subsection{Granger causality test and results}

The existence of a co-integrating relationship between the variables of interest may suggest that there must be Granger causality in at least one direction, but does not show the direction of temporal causality between the variables (Narayan \& Smyth, 
2004). The null hypothesis states that $x$ does not granger-cause $y$. On the other hand, the long-run causality can be examined by the significance of the t-statistics on the coefficient of the lagged error correction term. There are three possible scenarios emanating from causality test results; causality can be unidirectional, bidirectional or non-existent (Narayan, 2005). The existence of a long-run relationship between economic growth rate and tax burden indicates that the Granger causality must at least run in one direction. Therefore, the study tests for the direction of causality by estimation of Eq. (13) with the lagged error correction term. The error correction model and results are presented as follows:

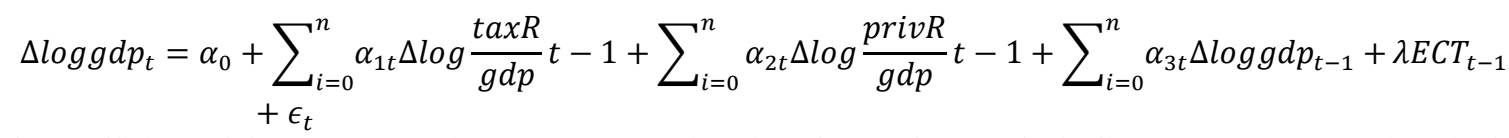

The coefficient of the error correction term, $E C T_{t-1}$ is referred to as the speed of adjustment parameter, since it shows how much of the disequilibrium in the previous period is corrected in the current period. It is expected to lie between 0 and -1 showing the degree of correction, with values closer to -1 being considered more significant. When this coefficient is equal to or above -1 , it may be indicative of immediate adjustment, however, at 0.5 , the adjustment would be occurring in each period (Narayan, 2005). The coefficients of the first differenced variables indicate the short run impact.

Table 4

Granger Causality results

\begin{tabular}{llllc}
\hline Dependent Variable & Causal flow & F-Statistic & test on ECT & R-squared \\
\hline Lrgdp & lrgdp $\rightarrow$ ltaxrgdp & $5.596293 \times$ & $-1.009122 \times(0.0033)$ & 0.504339 \\
Ltaxrgdp & ltaxrgdp $\rightarrow$ lrgdp & $0.853907(0.478292)$ & 0.096444 \\
\hline Note: $p$-values are in parentheses and * denotes the level of statistical significance at 1\%. &
\end{tabular}

The short-run causal effect from economic growth to tax burden is supported by the statistically significant $F$-statistic, while the coefficient of the error-correction term, which is negative and statistically significant, provides support for the long-run causality from economic growth to tax burden in Lesotho.

\subsection{Error Correction results analysis}

Error correction regression results in Table 1 shows that we cannot calculate an optimal tax burden during the period from 1988 to 2017 since Scully's model requires the regression coefficients for tax burden and private receipts to be positive and significant in order to establish an optimal point using equation 4.9. This is due to negative regression coefficients for both tax burden and private receipts. The regression results show that both tax burden and share of private receipts had been insignificant in influencing the economic growth rate in Lesotho. This implies that tax policy had an insignificant impact on economic growth in Lesotho during the period under study.

\section{Table 6}

Error correction regression results

Dependent Variable D(LRGDP)

Method: Least squares

Sample adjusted: 1990-2016

Included Observations: 27

\begin{tabular}{|c|c|c|c|c|}
\hline & Coefficient & Std. Error & t-statistic & Prob. \\
\hline $\mathrm{C}$ & -0.016349 & 0.181946 & -.089857 & 0.9292 \\
\hline D(LRGDP(-1)) & -0.001168 & 0.217182 & -0.005377 & 0.9958 \\
\hline D(LTAXRGDP(-1)) & -0.820486 & 1.556412 & -0.527165 & 0.6034 \\
\hline D(LPRIVRGDP(-1)) & -5.303146 & 13.41086 & -0.395437 & 0.6963 \\
\hline $\operatorname{ECT}(-1)$ & -1.009122 & 0.305913 & -3.298717 & 0.0033 \\
\hline R-squared & 0.504339 & \multicolumn{2}{|c|}{ Mean Dependent VAR } & -0.022162 \\
\hline Adjusted R-squared & 0.414219 & \multicolumn{2}{|c|}{ S.D. Dependent VAR } & 0.940995 \\
\hline F-statistic & 5.596293 & \multicolumn{2}{|c|}{ Akaike info. criterion } & 2.347010 \\
\hline Prob. (F-statistic) & 0.002905 & \multicolumn{2}{|c|}{ Schwarz Criterion } & 2.586980 \\
\hline & & \multicolumn{2}{|c|}{ Durbin-Watson Stat } & 2.067533 \\
\hline
\end{tabular}

The findings are consistent with the findings of Matloja et al. (2016) who employed the ARDL bounds test approach of Perasan et al. (2001) to the tax optimizing growth model of Scully (2003) for a sample period before and after the global recession period in South Africa. Their findings revealed a non-existent relationship between share of tax revenue to GDP and economic growth in the period prior to the recession which they attributed to ineffectiveness of tax policy in influencing economic growth during the period. Zachary and Canicio (2014) also found similar results to this study when examining the causal relationship between Government tax revenue growth and economic growth in Zimbabwe during 1980-2012 period. 
They employed the Granger causality test, Johansen's co-integration test and the vector error correction model and found that there is an independence relationship between tax revenue and GDP growth.

\section{Conclusion}

The purpose of this study was to establish whether tax burden has an impact on the rate of economic growth in the Lesotho context and to estimate an optimal tax burden, over the period 1988 to 2017 . The ARDL bounds test framework was employed to establish co-integration and whether a long-run relationship exists between tax burden and economic growth. The results established a co-integration relationship between economic growth rate and tax burden with a unidirectional causality running from economic growth to tax burden. Granger causality revealed no causal effect running from tax burden to economic growth in Lesotho. The results portrayed the insignificance of tax policy in influencing economic activity in Lesotho during the period under study. However, the error correction model results signified a long-run relationship between economic growth rate and tax burden in Lesotho with a $100 \%$ speed of adjustment to long-run equilibrium following a shock in the short-run. The results of the study are consistent with various results in the literature such as Zachary and Canicio, (2014) for Zimbabwe and Matloja et al. (2016) for South Africa. To estimate the optimal tax burden, Scully's tax optimization model requires positive and significant regression coefficients for tax burden and private receipts. The regression results revealed negative and insignificant coefficients; therefore, the optimal tax burden could not be determined as a result. Based on the findings of insignificant relationship between tax burden- defined as share of tax revenue to GDP, and economic growth revealed by the Granger causality and error correction results, we recommend development of pro-growth policies that will ensure direction of tax revenue collections towards developmental programs such as infrastructure development to stimulate private sector economic activity. We also recommend good domestic tax revenue mobilization to provoke a resilient economy which is less reliant on external financing and grants for infrastructural developments and an economy that has capacity to guard against external shocks.

\section{References}

Abuselidze, G. (2015). Formation of Tax Policy in the Aspect of the Optimal Tax Burden. International Review of Management and Business Research, 4(3).

Aktan, C. (1989, January). Supply-side economics and supply-side fiscal policy. Research Gate.

Amgain, J. (2017). Estimal optimal level of taxation for maximization in India. Applied Economics and Finance, 4(3), 2332.

Attila, G. (2011, January 17). Corruption, taxation and economic growth: theory and evidence. HAL.

Budget Speech. (2018). Budget Speech. Maseru: Lesotho Government.

Canicio, D., \& Zachary, T. (2014). Causal Relationship between Government Tax Revenue Grwoth and Economic Growth: A case of Zimbabwe. Journal of Economics and Sustainable Development, 5(17).

Chokri, T. E. (2018). Optimal Taxation and Economic Growth in Tunisia: Short and Long. Journal of Reviews in Global Economics, 7, 157.

Eyo, J. M., Chika, H., Friday, M. \&., Nimenibo, A., \& Samuel, A. W. (2018). An Empirical Analysis of Tax Revenue and Economic Growth in Nigeria from 1980 to 2015. Global Journal of Human Social Science and Political Science, 18(3).

Hunady, J., \& Orviska, M. (2015). The Non-Linear effect of Corporate taxes on Economic growth. Timisoara Journal of Economics and Business, 8(1), 14-31.

IMF. (2017). Fiscal Rules: Coping with Revenue volatility in Lesotho and Swaziland. Washington DC: IMF.

Jayeola, O., Naimot, O.A., Oladele, S.A., Olufemi, S.A. (2018). Tax Revenue and Economic growth in Nigeria. Scholedge International Journal of Management \& Development, 5(7).

Keho, Y. (2010). Estimating the growth-maximizing tax rate for Cote. Journal of Economics and International Finance, 2(9), 164-174.

Keho, Y. (2013). The structure of taxes and economic growth in Cote D'Ivoire: An Econometric investigation. Journal of Research in Economics and International Finance, 2(3), 39-48.

Kennedy, P. E. (2000). On measuring the growth-maximizing tax rate. Pacific Economic Review, 5(1), 89-91.

Keynes, J. M. (1936). The General Theory of Employment, Interest and Money. Palgrave Macmillan.

Khumbuzile , D., \& Khobai, H. (2018). The impact of Taxation on Economic Growth in South Africa. Munich Personal RePEc Archive.

Koch, S. J., Schoeman, N. J., \& Van Tonder, J. J. (2005). Economic Growth and the structure of taxes in South Africa: 19602002. South African Journal of Economics, 73(2), 190-210.

Liu, H., Nguyen, H. C., \& Tran, T. H. (2012). Tax burdeb and economic growth: Theory and practice in Vietnam. 46(15).

LRA. (2016). Annual Report. Maseru: Lesotho Revenue Authority.

Macek, R. (2014). The impact of taxation on economic growth: The case of OECD countries. Review of Economic Perspectives, 14(4), 309-328.

Matloja, L., Makhoana, T., Kassoma, R., Houdman, R., \& Phiri, A. (2016). Changes in the optimal tax rate in South Africa prior and subsequent to the global recession period. Munich Personal RePEc.

Narayan, P. K. (2005). The saving and investment nexus for China: evidence from cointegration tests. Applied Economics, 37(17), 1979-1990. 
Narayan, P. K., \& Smyth, R. (2004). Temporal Causal and the dynamics of exports, human capital and real income in China. International Journal of Applied Economics, 1(1), 24-25.

Odhiambo, O., \& Olushola, O. (2016). Taxation and economic growth in a resource-rich country: The case of Nigeria. IntechOpen, 10.5772(74381).

Pesaran, M., Shin, Y., \& Smith, R. (2001). Bounds testing approaches to the analysis of level relationships. Journal of Applied Econometrics 16, 289-326.

Phiri, A. (2016). The growth trade-off between direct and indirect taxes in South Africa: Evidence from a STR model. Munich Personal RePEC Archive, p. 69152.

Romer, D. D., \& Romer, C. H. (2010). The macroeconomic effects of tax changes: Estimates based on a new measure of fiscal shocks. American Economic review, 100, 763-801.

SACU. (2017). Annual Report. Windhoek: SACU.

Saibu, O. (2015). Otimal Tax Rate and Economic Growth: Evidence from Nigeria and South Africa. EuroEconomica, 34(1).

Scully, G. W. (2003). Optimal Taxation, economic growth and income inequality. Public Choice, 299-312.

Takuma, W., \& Iyke, B. N. (2015, January 5). The links between economic growth and tax revenue in Ghana: An empirical investigation. Munich Personal RePEC Archive, 76010.

Thamae, R. (2013). The growth of government spending in Lesotho. Economic Analysis and Policy, 3(43), $339-352$.

Zachary, T., \& Canicio, D. (2014). Causal Relationship between Government Tax Revenue Growth and Economic growth:A case of Zimbabwe. Journal of Economics and Sustainable Development.

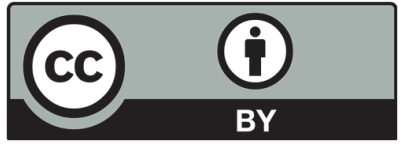

(C) 2021 by the authors; licensee Growing Science, Canada. This is an open access article distributed under the terms and conditions of the Creative Commons Attribution (CC-BY) license (http://creativecommons.org/licenses/by/4.0/). 